\title{
Determination of oxygen radical production in spondyloarthropathies by whole blood chemiluminescence
}

\author{
Matti Ristola, Marjatta Leirisalo-Repo, Heikki Repo
}

\begin{abstract}
Oxygen derived free radicals are considered to play an important part in the development of inflammation. A whole blood chemiluminescence assay was used to study $\boldsymbol{N}$-formylmethionyl-leucyl-phenylalanine induced oxygen radical production in subjects with ankylosing spondylitis or previous yersinia arthritis. In luminol enhanced chemiluminescence, the subjects with previous yersinia arthritis showed significantly increased initial activation (at one minute), whereas the subjects with ankylosing spondylitis showed decreased responses at both the initial activation and at peak activation (at two to three minutes). This finding gives credence to the view that, in terms of oxygen radical production, the pathogenesis of yersinia arthritis is different from that of ankylosing spondylitis.
\end{abstract}

Reactive arthritis and ankylosing spondylitis are both strongly associated with the HLA-B27 antigen. ${ }^{1}$ Reactive arthritis, a sterile inflammatory arthropathy, can follow enteric infections by Yersinia enterocolitica, salmonellas, shigellas, and campylobacteria. ${ }^{2-5}$ In ankylosing spondylitis infectious agents such as klebsiella have been suggested as triggering factors of the disease. $^{67}$

The pathogenesis of spondyloarthropathies is unknown, but both an aberrant immune response $^{8}$ and inappropriate inflammatory hyperreactivity ${ }^{9}$ may be involved. Patients with yersinia arthritis have altered cell mediated and humoral immunity against yersinia. ${ }^{11}$ Serum samples from patients with acute yersinia arthritis have a stronger opsonic capacity than serum samples from patients with non complicated yersiniosis. ${ }^{12}$ The initial activation, but neither the peak response nor the area under the curve, in $N$-formyl-methionyl-leucylphenylalanine (fMLP) induced luminol enhanced whole blood chemiluminescence is increased in subjects with previous yersinia arthritis. ${ }^{13}$ In patients with previous yersinia arthritis the increased oxygen radical production from purified neutrophils is associated with the severity of the acute disease ${ }^{14}$ and the presence of sequelae, ${ }^{15}$ whereas in ankylosing spondylitis the neutrophil oxygen radical production is reported to be normal ${ }^{16}$ or decreased. ${ }^{17}$

The exact role of oxygen radicals in the inflammatory damage of arthritides is not known. ${ }^{18}$ The purpose of this work was to study oxygen radical production in patients with previous yersinia arthritis who had experienced severe or mild acute disease, with or without sequelae, in patients with ankylosing spondylitis, and in healthy subjects who were HLA-B27 positive or negative. Luminol and lucigenin enhanced responses were determined; the former measures mainly the reaction between hydrogen peroxide and myeloperoxidase, ${ }^{19}$ whereas the latter measures mainly superoxide production. ${ }^{20}$

\section{Patients and methods} PATIENTS

Twenty five HLA-B27 positive or negative subjects were selected from a follow up study group of patients with yersinia arthritis. ${ }^{21}$ The diagnosis of yersinia arthritis was based on the typical clinical symptoms of reactive arthritis ${ }^{22}$ and a raised agglutination antibody titre $(>1 / 160)$ for Yersinia enterocolitica $(0: 3$ or $0: 9)$, or a stool culture positive for the organism. The patients with previous yersinia arthritis were grouped according to the HLA-B27 antigen, the clinical features of acute disease, and the presence of sequelae (radiological sacroiliitis, enthesopathies, or iritis) during follow up (table 1). Seven HLA-B27 positive subjects with ankylosing spondylitis, who fulfilled the New York criteria for definite ankylosing spondylitis ${ }^{23}$ and who had had predominantly axial inflammation, were selected from patients at the outpatient clinic of the second department of

Table 1 Characteristics of the subject groups

\begin{tabular}{|c|c|c|c|}
\hline Characteristic & $\begin{array}{l}\text { Previous } \\
\text { yersinia } \\
\text { arthritis }\end{array}$ & $\begin{array}{l}\text { Ankylosing } \\
\text { spondylitis }\end{array}$ & $\begin{array}{l}\text { Healthy } \\
\text { subjects }\end{array}$ \\
\hline $\begin{array}{l}\text { Number of subjects } \\
\text { Men/women } \\
\text { HLA-B27 }\end{array}$ & $\begin{array}{l}25 \\
9 / 16\end{array}$ & $\begin{array}{l}7 \\
4 / 3\end{array}$ & $\begin{array}{l}20 \\
6 / 14\end{array}$ \\
\hline $\begin{array}{l}\text { positive-negative } \\
\text { Acute phase of }\end{array}$ & $18 / 7$ & $7 / 0$ & $10 / 10$ \\
\hline $\begin{array}{l}\text { yersinia arthritis } \\
\text { severe/mild } \\
\text { Sequelae after }\end{array}$ & $12 / 13$ & - & - \\
\hline $\begin{array}{l}\text { yersinia arthritis } \\
\text { present/absent }\end{array}$ & $10 / 15$ & & \\
\hline $\begin{array}{l}\text { Mean age in years } \\
\text { (range) }\end{array}$ & $\begin{array}{l}47 \\
(27-69)\end{array}$ & $\begin{array}{l}41 \\
(32-52)\end{array}$ & $\begin{array}{l}44 \\
(31-62)\end{array}$ \\
\hline $\begin{array}{l}\text { Mean period in years } \\
\text { (range) since yersinia } \\
\text { arthritis }\end{array}$ & $(10-19)$ & & \\
\hline $\begin{array}{l}\text { Mean period in years } \\
\text { (range) since symptoms } \\
\text { of ankylosing spondylitis }\end{array}$ & - & $\stackrel{12}{(3-20)}$ & - \\
\hline $\begin{array}{l}\text { Mean period in years } \\
\text { (range) since diagnosis } \\
\text { of ankylosing spondylitis }\end{array}$ & - & $\stackrel{6}{(2-13)}$ & - \\
\hline \multirow{3}{*}{$\begin{array}{l}\mathrm{C} \text { reactive protein }(\mathrm{mg} / \mathrm{l}) \\
<10 \\
10-19 \\
20-22\end{array}$} & 22 & 3 & 19 \\
\hline & 2 & 3 & 1 \\
\hline & 1 & 1 & \\
\hline
\end{tabular}

The subjects with severe yersinia arthritis showed at least two and the subjects with mild yersinia arthritis only one (or none), of the following characteristics: highest erythrocyte sedimentation rate $>110 \mathrm{~mm} / \mathrm{h}$; highest white blood cell count $>10 \times 10^{9} / 1$; presence of extra-articular manifestations (iritis/conjuctivitis, balanitis/pyuria, keratodermia blenorrhagica, or erythema nodosum). 
medicine of Helsinki University Central Hospital (table 1). The subjects had not taken non steroidal anti-inflammatory drugs. At the time of this study the subjects with ankylosing spondylitis or previous yersinia arthritis had no or few acute musculoskeletal symptoms and their serum concentrations of $\mathrm{C}$ reactive protein were normal or only slightly raised (table 1). The healthy control subjects (table 1) were HLA-B27 positive or negative healthy laboratory and hospital staff.

\section{STUDY DESIGN}

Blood samples from four HLA-B27 positive (with previous yersinia arthritis with sequelae, with previous yersinia arthritis without sequelae, with ankylosing spondylitis, or healthy) and two HLA-B27 negative (with previous yersinia arthritis or healthy) subjects were taken and tested on a single day.

BLOOD SAMPLES

Peripheral venous blood was mixed with preservative free heparin, $10 \mathrm{U} / \mathrm{ml}$ of blood, and the neutrophil count and haemoglobin concentration were determined. ${ }^{24}$

\section{DETERMINATION OF CHEMILUMINESCENCE}

Luminol enhanced chemiluminescence of whole blood samples was measured at $37^{\circ} \mathrm{C} .{ }^{24}$ In brief, $100 \mu$ l of blood was mixed with $200 \mu$ l of luminol (Fluka, Buchs, Switzerland) $(100 \mu \mathrm{g} /$ $\mathrm{ml}$ ) and $100 \mu \mathrm{l}$ of fMLP (Sigma Chemical, St Louis, MO, USA) $\left(10^{-5} \mathrm{~mol} / \mathrm{l}\right)$, or phosphate buffered saline, and the reaction was observed continuously for three minutes in an LKBWallac Luminometer 1250 with a chart recorder. In a study of 50 healthy adults by this assay, ${ }^{24}$ both IMLP and phosphate buffered saline induced chemiluminescence showed a peak response at two to three minutes. The one minute value representing the rate of increase in the initial activation ${ }^{24}$ and the peak response at two to three minutes ${ }^{24}$ (fig l) were used in the statistical analysis. To determine the lucigenin enhanced response, lucigenin (Sigma) was dissolved in Dulbecco's buffered saline at a concentration of $1 \mathrm{mmol} / 1$ and used instead of the luminol solution. The reaction was observed for three minutes and the peak response, recorded in millivolts, was calculated from the curve obtained.

The arithmetic mean of triplicate measurements was calculated and then converted to be equivalent to the chemiluminescence response of $2.5 \times 10^{9}$ neutrophils per litre in $135 \mathrm{~g} / \mathrm{l}$ haemoglobin with a correction factor based on both the neutrophil count and the haemoglobin concentration. ${ }^{24}$ The correction factor is based on an experimental study with cell mixtures ${ }^{24}$ in which the correlation of the neutrophil count with chemiluminescence was positive and linear, whereas the correlation of the haemoglobin concentration with chemiluminescence was negative and linearity was attained by logarithmic transformation. The corrected chemiluminescence values are presented.

\section{STATISTICS}

The significance of the difference between the groups was evaluated by the analysis of variance; we evaluated the effect of (1) previous yersinia arthritis and HLA-B27 among subjects with previous yersinia arthritis and healthy subjects; (2) clinical features among subjects with previous yersinia arthritis; (3) ankylosing spondylitis among subjects with ankylosing spondylitis and healthy subjects; and (4) type of spondyloarthropathy among HLA-B27 positive subjects who had ankylosing spondylitis, had had yersinia arthritis, or who were healthy. The significance of the difference between the subgroups with different clinical features of previous yersinia arthritis was evaluated by the Mann-Whitney $U$ test. On the basis of the analysis of the frequency distributions of all the parameters measured, logarithmic transformation of the data was performed before the analysis of variance and the geometric mean and standard error of the mean were used in the presentation of the data.

\section{Results}

YERSINIA ARTHRITIS AND THE HLA-B27 ANTIGEN The subjects with previous yersinia arthritis $(n=25)$ had higher responses than the healthy subjects $(n=20)$ for all the parameters analysed, except in the phosphate buffered saline induced one minute responses (table 2 ); the association

Table 2 Whole blood chemiluminescence in subject groups characterised in table 1. Results expressed in millivolts as geometric mean $(-1$ SEM; +1 SEM)

Figure 1 Luminol enhanced

\begin{tabular}{|c|c|c|c|c|c|c|}
\hline \multirow[t]{2}{*}{ Subjects } & \multirow{2}{*}{$\begin{array}{l}\text { Number } \\
\text { of subjects }\end{array}$} & \multicolumn{4}{|l|}{ Luminol enhanced } & \multirow{2}{*}{$\frac{\text { Lucigenin enhanced }}{\text { fMLP peak }}$} \\
\hline & & $f M L P$ one minute & $f M L P$ peak & $P B S$ one minute & PBS peak & \\
\hline $\begin{array}{l}\text { Yersinia arthritis } \\
\text { HLA-BB27 positive } \\
\text { HLA-B27 negative } \\
\text { Sequelae present } \\
\text { Sequelae absent } \\
\text { Severe arthritis } \\
\text { Mild arthritis }\end{array}$ & $\begin{array}{l}25 \\
18 \\
7 \\
10 \\
15 \\
12 \\
13\end{array}$ & $\begin{array}{l}0.42(0.39 ; 0.45) \\
0.38(0.35 ; 0.41) \\
0.54(0.47 ; 0.63) \\
0.42(0.37 ; 0.47) \\
0.40(0.37 ; 0.45) \\
0.48(0.44 ; 0.53) \\
0.37(0.33 ; 0.41)\end{array}$ & $\begin{array}{l}0.65(0.60 ; 0.70) \\
0.61(0.56 ; 0.68) \\
0.73(0.61 ; 0.88) \\
0.66(0.56 ; 0.77) \\
0.64(0.58 ; 0.71) \\
0.71(0.64 ; 0.79) \\
0.59(0.52 ; 0.67)\end{array}$ & $\begin{array}{l}0.05(0.04 ; 0.06) \\
0.04(0.03 ; 0.05) \\
0.06(0.05 ; 0.07) \\
0.03(0.02 ; 0.04) \\
0.06(0.05 ; 0.07) \\
0.04(0.03 ; 0.05) \\
0.06(0.05 ; 0.07)\end{array}$ & $\begin{array}{l}0.12(0.11 ; 0.14) \\
0.11(0.10 ; 0.13) \\
0.16(0.13 ; 0.19) \\
0.11(0.09 ; 0.13) \\
0.14(0.12 ; 0.16) \\
0.13(0.11 ; 0.15) \\
0.11(0.09 ; 0.13)\end{array}$ & $\begin{array}{l}1.49(1.41 ; 1.57) \\
1.46(1.37 ; 1.56) \\
1.55(1.40 ; 1.72) \\
1.43(1.29 ; 1.60) \\
1.52(1.44 ; 11.61) \\
1.67(1.56 ; 1.78) \\
1.33(1.24 ; 1.44)\end{array}$ \\
\hline Ankylosing spondylitis & & $0.27(0.24 ; 0.31)$ & $0.43(0.38 ; 0.49)$ & $0.03(0.02 ; 0.04)$ & $0.08(0.07 ; 0.10)$ & $1.32(1.25 ; 1.39)$ \\
\hline $\begin{array}{l}\text { Healthy subjects } \\
\text { HLA-B27 positive } \\
\text { HLA-B27 negative }\end{array}$ & $\begin{array}{l}20 \\
10 \\
10\end{array}$ & $\begin{array}{l}0.34(0.32 ; 0.37) \\
0.38(0.35 ; 0.42) \\
0.31(0.27 ; 0.35)\end{array}$ & $\begin{array}{l}0.57(0.53 ; 0.60) \\
0.62(0.57 ; 0.67) \\
0.52(0.48 ; 0.56)\end{array}$ & $\begin{array}{l}0.05(0.04 ; 0.07) \\
0.05(0.04 ; 0.07) \\
0.05(0.04 ; 0.06)\end{array}$ & $\begin{array}{l}0.11(0.09 ; 0.13) \\
0.13(0.10 ; 0.16) \\
0.09(0.07 ; 0.12)\end{array}$ & $\begin{array}{l}1.33(1.23 ; 1.44) \\
1.29(1.18 ; 1.42) \\
1.37(1.24 ; 1.52)\end{array}$ \\
\hline
\end{tabular}

Abbreviations: $\mathrm{fMLP}=N$-formyl-methionyl-leucyl-phenylalanine; $\mathrm{PBS}=$ phosphate buffered saline

*The one minute responses were almost the same in all groups (data not shown). 
was signiticant in the luminol enhanced fMLP induced one minute responses $(p=0.028$; table 3, fig 2A).

When the effect of the presence of the HLAB27 antigen was analysed in subjects with yersinia arthritis and healthy subjects the effect of the presence of HLA-B27 was not statistically significant (table 3). However, the healthy subjects with HLA-B27 $(n=10)$ had higher responses than those without HLA-B27 $(n=10)$ (table 2), although the difference was not statistically significant.

CLINICAL FEATURES OF YERSINIA ARTHRITIS The subjects who with previous severe yersinia arthritis $(n=12)$ showed higher responses in all the parameters analysed than those who with previous mild yersinia arthritis $(n=13)$, except for the one minute responses in phosphate buffered saline induced chemiluminescence (table 2); the difference was significant in lucigenin enhanced peak responses $(p=0.009)$; table 3)

When the subgroups with different clinical features of previous yersinia arthritis were compared the subjects with mild arthritis with sequelae present showed low responses in all the parameters analysed (table 4, fig 2B). In the luminol enhanced fMLP induced peak responses, the difference between the subgroup with mild arthritis with sequelae present and the subgroup with severe arthritis with sequelae present was significant $(p<0.05$; table 4$)$. In the phosphate buffered saline induced one minute responses the difference between the
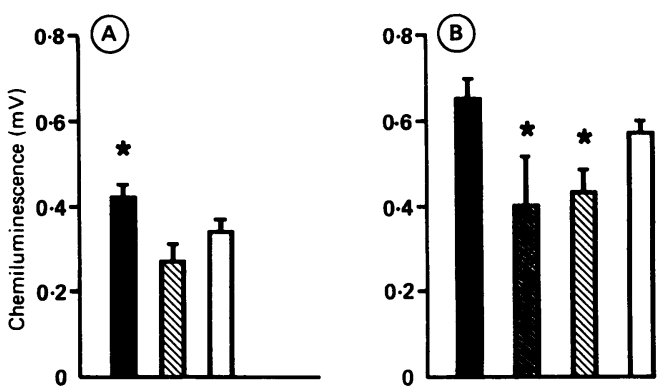

Figure 2 Comparison of luminol enhanced $\mathrm{N}$-formylmethionyl-leucyl-phenylalanine induced chemiluminescence between the subject groups described in table 1. Previous yersinia arthritis (ם), previous yersinia arthritis with mild

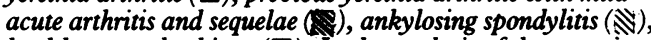
healthy control subjects $(\square)$. In the analysis of the one minute values $(A)$ previous yersinia arthritis was associated with significantly increased chemiluminescence responses. In the analysis of peak values $(B)$ both ankylosing spondylitis and previous yersinia arthritis with mild acute arthritis and sequelae were associated with significantly decreased chemiluminescence responses. Each column represents the geometric mean of the group and each bar one standard error of the mean. Statistical significance is indicated by asterisks (for the exact statistical analysis, see tables 2-4).

Table 3 Analysis of variance of whole blood chemiluminescence responses

\begin{tabular}{|c|c|c|c|c|c|c|c|c|c|c|c|}
\hline \multirow[t]{3}{*}{ Subjects } & \multirow{3}{*}{$\begin{array}{l}\text { Degrees } \\
\text { of } \\
\text { freedom }\end{array}$} & \multicolumn{8}{|c|}{ Luminol enhanced } & \multirow{2}{*}{\multicolumn{2}{|c|}{$\frac{\text { Lucigenin enhanced }}{\text { fMLP peak }}$}} \\
\hline & & \multicolumn{2}{|c|}{$f M L P$ one minute } & \multicolumn{2}{|c|}{$f M L P$ peak } & \multicolumn{2}{|c|}{ PBS one minute } & \multicolumn{2}{|c|}{$P B S$ peak } & & \\
\hline & & $F$ & $p$ & $F$ & $p$ & $F$ & $p$ & $F$ & $p$ & $F$ & $p$ \\
\hline $\begin{array}{l}\text { Yersinia arthritis and HLA-B27 } \\
\text { Yersinia arthritis } \\
\text { HLA-B27 } \\
\text { Combined } \\
\text { Within }\end{array}$ & $\begin{array}{r}1 \\
1 \\
1 \\
41\end{array}$ & $\begin{array}{l}5 \cdot 313 \\
0 \cdot 425 \\
6 \cdot 290\end{array}$ & $\begin{array}{l}0.028^{*} \\
0.525 \\
0.015^{*}\end{array}$ & $\begin{array}{l}2 \cdot 185 \\
0 \cdot 017 \\
2 \cdot 331\end{array}$ & $\begin{array}{l}0 \cdot 143 \\
0.937 \\
0 \cdot 131\end{array}$ & $\begin{array}{l}0 \cdot 010 \\
0 \cdot 247 \\
1 \cdot 803\end{array}$ & $\begin{array}{l}0.885 \\
0.628 \\
0 \cdot 184\end{array}$ & $\begin{array}{l}1 \cdot 165 \\
0 \cdot 016 \\
3 \cdot 483\end{array}$ & $\begin{array}{l}0.289 \\
0.867 \\
0.069\end{array}$ & $\begin{array}{l}1.864 \\
0.431 \\
0.001\end{array}$ & $\begin{array}{l}0.176 \\
0.522 \\
0.935\end{array}$ \\
\hline $\begin{array}{l}\text { Clinical features of yersinia arthriti } \\
\text { Sequelae absent or present } \\
\text { Severe or mild arthritis } \\
\text { Combined } \\
\text { Within }\end{array}$ & $\begin{array}{r}1 \\
1 \\
1 \\
21\end{array}$ & $\begin{array}{l}0 \cdot 552 \\
3 \cdot 240 \\
2 \cdot 150\end{array}$ & $\begin{array}{l}0.472 \\
0.083 \\
0.154\end{array}$ & $\begin{array}{l}0 \cdot 285 \\
2 \cdot 807 \\
5 \cdot 373\end{array}$ & $\begin{array}{l}0 \cdot 605 \\
0 \cdot 105 \\
0 \cdot 030^{*}\end{array}$ & $\begin{array}{l}3 \cdot 478 \\
0 \cdot 032 \\
4 \cdot 128\end{array}$ & $\begin{array}{l}0.073 \\
0.837 \\
0.052\end{array}$ & $\begin{array}{l}2 \cdot 648 \\
1 \cdot 519 \\
7 \cdot 208\end{array}$ & $\begin{array}{l}0.115 \\
0.230 \\
0.013^{*}\end{array}$ & $\begin{array}{l}2 \cdot 786 \\
8 \cdot 334 \\
1 \cdot 833\end{array}$ & $\begin{array}{l}0 \cdot 107 \\
0 \cdot 009+ \\
0 \cdot 188\end{array}$ \\
\hline $\begin{array}{l}\text { Ankylosing spondylitis } \\
\text { Ankylosing spondylitis or healthy } \\
\text { Within }\end{array}$ & $\begin{array}{r}1 \\
25\end{array}$ & $2 \cdot 241$ & $0 \cdot 144$ & $5 \cdot 073$ & $0.031^{*}$ & $1 \cdot 391$ & $0 \cdot 248$ & $1 \cdot 059$ & $0 \cdot 314$ & 0.012 & 0.878 \\
\hline $\begin{array}{l}\text { Type of spondyloarthropathy in } \mathbf{H} \\
\text { Yersinia arthritis, ankylosing } \\
\text { spondylitis, or healthy } \\
\text { Within }\end{array}$ & $\begin{array}{l}\text { HLA-B27 } \\
2 \\
30\end{array}$ & positive & $\begin{array}{l}\text { subjects } \\
0.087\end{array}$ & $2 \cdot 777$ & 0.076 & 0.915 & 0.414 & $1 \cdot 307$ & $0 \cdot 284$ & 0.908 & 0.416 \\
\hline
\end{tabular}

Abbreviations: $\mathrm{fMLP}=N$-formyl-methionyl-leucyl-phenylalanine; $\mathrm{PBS}=$ phosphate buffered saline

${ }^{*} \mathrm{p}<0.05$.

$\mathrm{tp}<0.01$

Table 4 Whole blood chemiluminescence in subjects with previous yersinia arthritis grouped according to the severity of acute arthritis and the presence of sequelae. Results expressed in millivolts as geometric mean $(-1 S E M ;+1 S E M)$

\begin{tabular}{|c|c|c|c|c|c|c|}
\hline \multirow[t]{2}{*}{ Subjects } & \multirow{2}{*}{$\begin{array}{l}\text { Number } \\
\text { of } \\
\text { subjects }\end{array}$} & \multicolumn{4}{|l|}{ Luminol enhanced } & \multirow{2}{*}{$\begin{array}{l}\text { Lucigenin enhanced } \\
\text { fMLP peak }\end{array}$} \\
\hline & & fMLP one minute & $f M L P$ peak & PBS one minute & PBS peak & \\
\hline \multirow{4}{*}{$\begin{array}{l}\text { Mild arthritis/ } \\
\text { sequelae present } \\
\text { Mild arthritis/ } \\
\text { sequelae absent } \\
\text { Severe arthritis/ } \\
\text { sequelae present } \\
\text { Severe arthritis/ } \\
\text { sequelae absent }\end{array}$} & 3 & $0.29(0.21 ; 0.40)$ & $0.40(0.31 ; 0.52)^{*}$ & $0.02(0.01 ; 0.03) \dagger$ & $0.05(0.05 ; 0.06) \ddagger$ & $1.04(0.86 ; 1.27)$ \\
\hline & 10 & $0.42(0.38 ; 0.47)$ & $0.66(0.58 ; 0.76)$ & $0.07(0.06 ; 0.09)$ & $0.15(0.13 ; 0.18)$ & $1.44(1.35 ; 1.54)$ \\
\hline & 7 & $0.50(0.46 ; 0.55)$ & $0.81(0.71 ; 0.93)$ & $0.04(0.03 ; 0.06)$ & $0.14(0.11 ; 0.17)$ & $1.64(1.48 ; 1.82)$ \\
\hline & 5 & $0.44(0.37 ; 0.54)$ & $0.59(0.50 ; 0.69)$ & $0.04(0.02 ; 0.07)$ & $0.11(0.09 ; 0.13)$ & $1.70(1.55 ; 1.86)$ \\
\hline
\end{tabular}

Abbreviations: $\mathrm{fMLP}=N$-formyl-methionyl-leucyl-phenylalanine; $\mathrm{PBS}=$ phosphate buffered saline

${ }^{*}$ Mild arthritis/sequelae present $v$ severe arthritis/sequelae present; $p<0.05$.

Mild arthritis/sequelae present $v$ mild arthritis/sequelae absent; $\mathrm{p}<0.05$.

$¥$ Mild arthritis/sequelae present $v$ mild arthritis/sequelae absent, mild arthritis/sequelae present $v$ severe arthritis/sequelae present, mild arthritis/sequelae present $v$ severe arthritis/sequelae absent; $\mathbf{p}<0.05$ in all instances. 
subgroup with mild arthritis with sequelae present and the subgroup with mild arthritis with sequelae absent was significant $(\mathrm{p}<0.05$; table 4). In the phosphate buffered saline induced peak responses the difference between the subgroup with mild arthritis with sequelae present and each of the other three subgroups was statistically significant at the $5 \%$ level (table 4).

\section{ANKYLOSING SPONDYLITIS}

The subjects with ankylosing spondylitis $(n=7)$ had lower responses than the healthy subjects $(n=20)$ in all the parameters measured (table 2): the difference was significant in luminol enhanced fMLP induced peak responses ( $p=0.031$; table 3 , fig 2B).

\section{COMPARISON OF THE TYPE OF SPONDYLOARTHROPATHY}

When the responses of HLA-B27 positive subjects were analysed among subjects with ankylosing spondylitis $(n=7)$, with previous yersinia arthritis $(n=18)$, or who were healthy $(n=10)$ the difference between the subjects with ankylosing spondylitis and subjects with yersinia arthritis was significant in luminol enhanced fMLP induced one minute $(p<0.05)$ and peak responses $(p<0.05)$ in the post hoc analysis of variance (Newman-Keuls test).

\section{Discussion}

The results of this study indicate that subjects with previous yersinia arthritis show an increase of whole blood chemiluminescence; this agrees with the previous findings by luminol enhanced chemiluminescence induced by fMLP or opsonised zymosan. ${ }^{13}$ The increase of chemiluminescence in subjects with previous yersinia arthritis was not associated with the HLA-B27 antigen, which supports the view that other factors may be involved in neutrophil responses in spondyloarthropathies. ${ }^{25}$

The increase in chemiluminescence was more evident in the subjects with previous severe yersinia arthritis (tables 2 and 3 ), which agrees with the results obtained with purified neutrophils. ${ }^{14}$ The initial activation in luminol enhanced chemiluminescence induced by fMLP, ${ }^{26} 27$ and the lucigenin enhanced chemiluminescence ${ }^{28}$ are considered to associate with extracellular oxygen radical production. It is possible that vigorous extracellular oxygen radical production, measured in this study by the initial activation of FMLP induced luminol enhanced chemiluminescence and by the peak of lucigenin enhanced chemiluminescence, contributes to the acute inflammatory damage in patients with yersinia arthritis. Yersinia and salmonella antigens have been demonstrated in the phagocytes of synovial fluid from patients with reactive arthritis. ${ }^{29} 30$ Yersinia may persist in the host ${ }^{31}$ and possibly stimulates the phagocytes for prolonged periods of time. It has been reported that etretinate, a known antioxidant, ${ }^{32}$ normalised superoxide formation by neutrophils and ameliorated markedly severe reactive enteroarthritis triggered by Salmonella infantis. ${ }^{33}$
In contrast, in ankylosing spondylitis we noted that the luminol enhanced chemiluminescence responses to fMLP were decreasea (table 2), in accordance with a previous study on opsonised zymosan induced chemiluminescence. ${ }^{17}$ Ankylosing spondylitis has been previously associated with a normal neutrophil superoxide formation induced by $\mathrm{AMLP},{ }^{16}$ phorbol myristate, or calcium ionophore, ${ }^{17}$ or a decreased neutrophil superoxide formation induced by opsonised zymosan ${ }^{17}$ determined by a cytochrome $c$ reduction assay. In this study superoxide formation in ankylosing spondylitis, determined by the lucigenin enhanced chemiluminescence test, was decreased, but the decrease was not statistically significant. Decreased oxygen radical production is further supported by the finding that in subjects with ankylosing spondylitis the oxygen consumption of neutrophils was decreased when the cells were stimulated by opsonised zymosan but not by phorbol myristate or by calcium ionophore. ${ }^{17}$ The aberration in oxygen radical production may be increased by a membrane receptor modification or by a disorder in the transduction of the activating signal as suggested by $\mathrm{El}$ Abbouyi et al. ${ }^{17}$

The opposite types of aberrations in oxygen radical production may reflect differences in the pathogenesis of yersinia arthritis and ankylosing spondylitis. Yersinia arthritis is characterised by an acute onset after an enteric infection, whereas ankylosing spondylitis develops insidiously without an obvious triggering infection. ${ }^{34}$ Interestingly, in this study the subjects with previous yersinia arthritis who had had mild acute arthritis and sequelae during the follow up, with a clinical picture resembling that of ankylosing spondylitis, had low responses in the peak values of MLP induced luminol enhanced chemiluminescence in a similar manner to the subjects with ankylosing spondylitis.

The pathogenesis of spondyloarthropathies is probably multifactorial ${ }^{35}$ and may involve aberrations in humoral and cellular immunity $^{9-123637}$ and increased permeability of the gut. ${ }^{38} 39$ The results of this study indicate that oxygen radical production from stimulated neutrophils, tested here concurrently, is increased in subjects with previous yersinia arthritis and decreased in subjects with ankylosing spondylitis. The mechanisms underlying these aberrations and whether the aberrations have different roles in the pathogenesis of seronegative spondyloarthropathies remain to be studied.

The authors thank Mrs Paula Rahikainen and Mrs Eine Virolainen for skilful technical assistance. This study was supported by grants from Hoechst Fennica Medical Research Foundation and the Finnish Rheumatism Research Foundation.

1 Brewerton D A. HLA-B27 and the inheritance of susceptibility to rheumatic diseases. Arthritis Rheum 1976; 19:656-68. Ahvonen O, Sievers K, Aho K. Arthritis associated with Yersinia enterocolitica infection. Acta Rheum Scand 1969; 15:
Y 232-53.

3 Berglö F-E. Arthritis and intestinal infection. Acta Rheum Scand 1963; 9: 141-9.

4 Paronen I. Reiter's disease: study of 344 cases observed in Finland. Acta Med Scand 1948; suppl 212: 1-114.

5 Urman J D, Zurier R B, Rothfield N F. Reiter's syndrome associated with Campylobacter fetus infection. Ann Intern Med 1977; 86: 444-5. 
6 Ebringer A, $\operatorname{Cox} \mathrm{N}$ L, Abuljadayel I Ghuloom M, Khalafpour S, Ptazynska T, Shodjai-Moradi F, Wilson C. Klebsiella antibodies in ankylosing spondylitis and proteus antibodies in rheumatoid arthritis. $\mathrm{Br} \mathcal{Y}$ Rheumatol 1988; 27 (suppl II):72-85.

7 Schwimmbeck P I, Yu D T Y, Oldstone M B A. Autoantibodies to HLA B27 in the sera of HLA-B27 patients with ankylosing spondylitis and Reiter's syndrome. Molecular mimcry with Klebsiella pneumoniae as potential mechanism of autoimmune disease. $\mathcal{F}$ Exp Med 1987; 166: 173-81.

8 Rosenbaum J T. Why HLA-B27: an analysis based on two animal models. Ann Intern Med 1981; 94: 261-3.

9 Repo H, Leirisalo M, Koivuranta P, Osterman T, Kiistala U, Gahmberg C G, Vapaatalo H, Tiilikainen A, Laitinen O
Neutrophil function and HLA-B27. Br $\mathcal{F}$ Rheumatol 1983 22 Suppl 2: 168-71.

10 Sheldon $P$. Specific cell-mediated responses to bacterial antigens and clinical correlations in reactive arthritis, Reiter's gens and clinical correlations in reactive arthritis, Reiter's 86: 5-25.

11 Toivanen A, Granfors $K$, Lahesmaa-Rantala $R$, Leino $R$ Ståhlberg T, Vuento R. Pathogenesis of yersinia-triggered reactive arthritis: immunological, microbiological and clinical aspects. Immunol Rev 1985; 86: 47-70.

12 Tertti R, Granfors KI, Lahesmaa-Rantala R, Toivanen A Serum opsonic capacity against Yersinia enterocolitica 0:3 in yersiniosis patients with and without reactive arthritis. Clin Exp Immunol 1989; 76: 227-32.

13 Ristola $M$. Increased oxygen radical production determined by whole blood chemiluminescence in patients with previous yersinia arthritis. APMIS 1990; 98: 125-30.

14 Koivuranta-Vaara P, Leirisalo-Repo M, Repo H. Polymorphonuclear leucocyte function and previous yersinia morphonuclear leucocyte function and previous yersinia arthritis: enhanced chemokinetic migration and oxyradical production correlate with seve

15 Repo H, Koivuranta-Vaara P, Leirisalo-Repo M. Polymorphonuclear leucocyte function and previous yersinia arthritis: correlation of enhanced superoxide production with late manifestations. Ann R heum Dis 1988; 47: 452-7.

16 Miller C, Russell A S. The generation of superoxide anions by polymorphonuclear leucocytes from patients with ankylosing spondylitis in response to the stimulant f-met-leu-phe. Clin Exp Rheumatol 1986; 4: 135-7.

17 El Abbouyi A, Paul J L, Roch-Arveiller M, Moachon L Dougados M, Giroud J P, Amor B, Raichvarg D. Blood pougados M, Giroud J P, Amor B, Raichvarg D. Blood polymorphonuclear behavior in patients with ank

18 Merry P, Winyard P G, Morris C J, Grootveld M, Blake D R. Oxygen free radicals, inflammation, and synovitis: the current status. Ann Rheum Dis 1989; 48: 864-70.

19 Allen R C. Phargocytic leukocyte oxygenation activities and chemiluminescence: a kinetic approach to analysis. Methods Enrymol 1986; 133: 449-93.

20 Gyllenhammar $H$. Lucigenin chemiluminescence in the assessment of neutophil superoxide production. $\mathcal{f}$ Immunol Methods 1987; 97: 209-13.

21 Leirisalo-Repo M, Suoranta H. Ten-year followup study of with yersinia arthritis. Arthritis Rheum 1988; 31: 533-7.

22 Leirisalo-Repo M. Clinical picture of reactive arthritis. Scand f Rheumatol Suppl 1984; 52: 65-9.
23 Bennett P H, Burch T A. Population studies of rheumatic diseases. Amsterdam: Excerpta Medica, 1968: 305.

24 Ristola M, Repo H. Luminol-enhanced chemiluminescence of whole blood: statistical analysis, and comparison of the responses of different subjects. APMIS 1989;97: 503-12.

25 Pease C T, Fennell M, Brewerton D A. Polymorphonuclear leucocyte motility in men with ankylosing spondylitis. Ann Rheum Dis 1989; 48: 35-41.

26 Bender J G, Van Epps D E. Analysis of the bimodal chemiluminescence pattern stimulated in human neutrophils by chemotactic factors. Infect Immun 1983; 41: 1062-70.

27 Dahlgren C. Effects on extra- and intracellularly localized, chemoattractant-induced, oxygen radical production of neutrophils following modulation of conditions for ligandreceptor interaction. Inflammation 1988; 12: 335-49.

28 Dahlgren C, Aniansson H, Magnusson K-E. Pattern of formylmethionyl-leucyl-phenylalanine-induced luminoland lucigenin-dependent chemiluminescence in human and lucigenin-dependent chemiluminescenc

29 Granfors $\mathrm{K}$, Jalkanen S, von Essen R, et al. Yersinia antigens in synovial-fluid cells from patients with reactive arthritis. N Engl f Med 1989; 320: 216-21.

30 Granfors K, Jalkanen S, Lindberg A A, et al. Salmonella lipopolysaccharide in synovial cells from patients with reactive arthritis. Lancet 1990; 335: 685-8.

31 Hoogkamp-Korstanje J A, de Koning J, Heeseman J. Persistence of Yersinia enterocolitica in man. Infection 1988; 16: 81-5.

32 Camisa C, Eisenstadt B, Ragaz A, Weissman G. The effects of retinoids on neutrophil

33 Repo H, Koivurant 620-9. P, Leirisalo-Repo M, Lauharanta $J$, Osterman T, Vapaatalo $H$. Etretinate therapy and neutrophil function in a patient with reactive arthritis triggered by salmonella infantis. Clin Exp Rheumatol 1987; 5: 388-90.

34 Calin A. Spondylarthropathies: an overview. In: Calin A, ed. Spondylarthropathies. Orlando: Grune and Stratton, 1984: 1-8.

35 van Bohemen C G, Nabbe A J J M, Landheer J E, et al. HLA-B27M1M2 and high immune responsiveness to 1986; 13: $71-4$.

36 Chen J-H, Kono D H, Yong Z, Park M S, Oldstone M M B A Yu D T Y. Yersinia pseudotuberculosa protein which crossreacts with HLA-B27. F Immunol 1987; 139: 3003-11.

37 Geczy A F, McGuigan L E, Sullivan J S, Edmonds J P Cytotoxic $T$ lymphocytes against disease associated determinant(s) in ankylosing spondylitis. $\mathcal{F}$ Exp Med 1986; 164: $932-7$.

38 Serrander R, Magnusson K-E, Kihlström E, Sundqvist T. Acute yersinia infections in man increase permeability for low-molecular weight polyethylene glycols (PEG 400). Scand J Infect Dis 1986; 18: 409-13.

39 Mielants H, Veys E M, De Vos M, Cuvelier C. Gut inflammation in the pathogenesis of idiopathic forms of reactive arthritis and in the peripheral joint involvement of ankylosing spondylitis. In: Mielants $\mathbf{H}$, Veys E M, eds. Spondyloarthropathies: involvement of the gut. Amsterdam: Spondyloarthropathes. 